\title{
The Impact of Work Characteristics on Bank Employees' Motivation in Hanoi: Application of Job Characteristics' Theory of Hackman and Oldham (1980)
}

\author{
Dinh Son Tang \\ Room Number 5, B6, KimLien, DongDa District, Hanoi city, Vietnam \\ (Phd Candidate of course's 35, National Economics University, Vietnam) \\ Duc Tai Do \\ University of Labor and Social Affairs, Vietnam
}

\begin{abstract}
This research was conducted to investigate the impact of of work characteristics on bank employees' motivation in Hanoi, Vietnam based on job characteristics' theory of Hackman and Oldham (1980). Data were collected through a survey with 150 bank employees from Hanoi. With this data, we have used Cronbach's Alpha, EFA and correlation analysis to determine the level of impact of the independent variable on the dependent variable, i.e. bank employees' motivation. The results showed that the determinant is the work characteristics which have positive relationships with bank employees' motivation in Hanoi. Based on this finding, this paper gives several recommendations for improvement bank employees' motivation in Hanoi.
\end{abstract}

Keywords: motivation, work characteristics, bank employees

JEL codes: M54, J53, G21

DOI: $10.7176 / \mathrm{EJBM} / 11-27-11$

Publication date:September $30^{\text {th }} 2019$

\section{Introduction}

Working motivation of employees is the source of promoting labor productivity, improving the quality of human resources, directly determining the existence and development of enterprises (Nguyen, 2017). Motivated employees have $80-90 \%$ of their productivity, low rates of absence and quit the job (Farhaan, 2009).

The commercial bank is a type of business in the field of currency, which requires human resource with professional knowledge of finance - currency. High-quality personnel or employees are the main assets which can lead any organization to success or if not focused well, to decline. As a result, employees' motivation becomes one of the most important concerns in banks' human resource management strategy, which can lead to tasks fulfillment and goals achievements.

Theory of Hackman and Oldham (1980) has been applied in a variety of work motivation studies and the findings suggest that work characteristics have a strong impact on employee motivation. In this study, we aimed to determine the impact of the "work characteristics" factor on the motivation of bank employees in Hanoi. The research result will make a contribution to developing human personnel strategies, which can be used as a reference or a basis to attract and retain high potential employees for the development of the bank.

\section{The job characteristics' theory of Hackman and Oldham}

Hackman and Oldham (1980) constructed a job characteristics model with five core aspects. The two authors said that if managers design works with the help of this model, employees will be satisfied with the job and as a result getting the high levels of performance.

According to Hackman and Oldham, internal motivation is something a desire that causes a person to strive and capture some accomplishment just because their work is worth doing and brings them a sense of satisfaction. The two authors described this motivation as the work itself. The five aspects of the work proposed by Hackman and Oldham are:

(i) Skill variety: The job enables people to sharpen and develop their skills and talents which they have a high demand for. If it assists them to enhance their professional competencies and promote their strengths, then they will realize the meaning of the work they are doing, thereby being satisfied and intrinsically motivated at work.

(ii) Task identity: The job clearly shows employees the completion degree of each part as well as the whole work. The requirement of work designing is to clarify the job specifications and the extent to which they have to complete. This is also a fundamental factor in motivating workers.

(iii) Task significance: What they are doing is valuable to others. Workers feel more motivated to attain greater productivity if they treasure the value of their contributions to others and the community.

(iv) Autonomy: The job allows people to be free, independent and have the right to decide or take part in the planning and controlling their performance. Autonomy at work can flourish virtual human capacities and 
responsibilities which leads to constant progress in coordination and work procedures.

(v) Feedback: The job allows workers to receive direct and clear information about their work performance. Hackman and Oldham (1980) suggested that in step with the other job characteristics, if the organization gives feedback on employees' work performance, people will be more satisfied and their motivation will increase. Therefore, employees will be less absent and less likely to quit the job.

According to Hackman and Oldham (1980), the first three aspects play a significant role in developing a wide range of skills, clear tasks and meaningful work that increases the value of work for an individual. Workers feel that what they contribute is important, valuable and helpful to everyone. The fourth aspect of work, "autonomy", suggests that if employees are empowered at work, they will execute their finest novelties and thoughts with the sense of responsibility. And if the job provides feedback on their performance (the fifth aspect), workers will know how to do it effectively. These incentives will lead to psychological expression of the individual (through attitude, behavior) and organizational effectiveness.

\section{Research Methodology}

Inheriting the results of previous studies by Hackman và Oldham (1980) and by using a qualitative research approach namely interviews with selected experts to perform a quantitative research, we have identified the following the factor that determining bank employees' motivation in Hanoi (BEM): work characteristics (WC).

Then, we made a questionnaire consisting of 12 observation variables with a 5-point Likert scale. Dependent variables are measured from 1 " not total agree" to 5 "Fully agree" (see Table 1). Independent variables are measured from 1 "without effect" to 5 "strongly" (see Table 2). The collection of data was done through a survey of 150 bank employees, for the period 2018-2019, close to this study period. Therefore, their feedback on the bank employees' motivation is considered very appropriate.

From 150 questionnaires we sent, we received the feedback of 130 respondents. After checking the information on the returned questionnaires, we have only 120 questionnaires with full information for data entry and analysis, the size of this sample is consistent with study of Hair et al (1998), namely $\mathrm{n}=5 \mathrm{x} \mathrm{m}=5 \times 12=60$. Therefore, the rest of observations for model 1 are 120 surveys $(80.0 \%)$. Most respondents have bachelor degree or higher (91.7\%). As can be seen, all participants are at high quality knowledge, and this makes surveys' answer are reliable.

We then used the EFA analysis and correlation analysis to determine the influence of the work characteristics determinant on the bank employees' motivation in Hanoi.

Dependent variable: Bank employees' motivation

Inheriting the results conducted by Herzberg et al. (1959), Bui \& Le (2014), Nguyen (2015), Bui \& Le (2016), Pham (2016), Nguyen (2017) and using qualitative research methodology through interviews with experts, we identify bank employees' motivation (BEM) including six attributes in table 1 as follows

Table 1: Attributes of bank employees' motivation

\begin{tabular}{|c|c|c|}
\hline Code & Scale & Source \\
\hline \multicolumn{3}{|c|}{ Bank employees' motivation (BEM) } \\
\hline BEM1 & Bank employees are excited about their current job & $\begin{array}{l}\text { Bui \&Le (2014), Nguyen (2015), Bui \& Le } \\
\text { (2016), Pham (2016), Nguyen (2017) }\end{array}$ \\
\hline BEM2 & Bank employees are always happy and optimistic & $\begin{array}{l}\text { Bui \&Le (2014), Bui \& Le (2016), Pham } \\
\text { (2016) }\end{array}$ \\
\hline BEM3 & $\begin{array}{l}\text { Bank employees are willing to sacrifice their own rights } \\
\text { to achieve good results in their job }\end{array}$ & $\begin{array}{l}\text { Bui \&Le (2014), Bui \& Le (2016), Pham } \\
\text { (2016) }\end{array}$ \\
\hline BEM4 & $\begin{array}{l}\text { Bank employees appreciate banks' policy about salary, } \\
\text { remuneration, working environment and conditions }\end{array}$ & $\begin{array}{l}\text { Bui \&Le (2014), Bui \& Le (2016), Pham } \\
\text { (2016), Nguyen (2017) }\end{array}$ \\
\hline BEM5 & $\begin{array}{l}\text { Bank employees are wiliing to go to work early or stay } \\
\text { late to finish their task }\end{array}$ & Nguyen $(2015)$ \\
\hline BEM6 & $\begin{array}{l}\text { Bank employees try their best to finish their job towards } \\
\text { banks' goals. }\end{array}$ & $\begin{array}{l}\text { Herzberg et al. (1959), Nguyen (2015), } \\
\text { Nguyen (2017) }\end{array}$ \\
\hline
\end{tabular}


Independent variable: The independent variable are described in Table 2.

Table 2: Determinants and Its Coding

\begin{tabular}{|l|l|l|}
\hline Code & \multicolumn{1}{|c|}{ Scale } & \multicolumn{1}{|c|}{ Source } \\
\hline Work characteristics (WC) & $\begin{array}{l}\text { Hackman \& Oldham (1980), Nguyen (2012), Nguyen \& } \\
\text { Pham (2017) }\end{array}$ \\
\hline WC1 & Requires a lot of skills & Hackman \& Oldham (1980), Nguyen \& Pham (2017) \\
\hline WC2 & Receive feedback on the job & Hackman \& Oldham (1980), Nguyen \& Pham (2017) \\
\hline WC3 & Appropriate with ability & $\begin{array}{l}\text { Hackman \& Oldham (1980), Nguyen (2012), Nguyen \& } \\
\text { Pham (2017) }\end{array}$ \\
\hline WC4 & Autonomy, challenging and exiting & Hackman \& Oldham (1980), Nguyen (2012) \\
\hline WC5 & The importance of the job & $\begin{array}{l}\text { Hackman \& Oldham (1980), Nguyen \& Pham (2017) } \\
\text { WC6 doing }\end{array}$ \\
\hline
\end{tabular}

\section{Research Model}

From the above analysis, we have designed a research model as shown in Figure 1.

\section{Work Characteristics (WC)}

Figure 1: Research model

\section{Research results}

\subsection{Descriptive Statistics}

Information of data collected is shown in Table 3

Table 3: Respondents by gender, age, department, education level and the average monthly salary

\begin{tabular}{|c|c|c|c|}
\hline & Frequency & Percent & Cumulative Percent \\
\hline \multicolumn{4}{|l|}{ Gender } \\
\hline Male & 63 & 52.5 & 52.5 \\
\hline Female & 57 & 47.5 & 100.0 \\
\hline \multicolumn{4}{|l|}{ Age } \\
\hline Over 45 years old & 10 & 8.3 & 8.3 \\
\hline From 22 to 34 years old & 36 & 30.0 & 38.3 \\
\hline From 35 to 45 years old & 74 & 61.7 & 100.0 \\
\hline \multicolumn{4}{|l|}{ Department } \\
\hline Accounting & 38 & 31.7 & 31.7 \\
\hline Control & 11 & 9.2 & 40.8 \\
\hline Business & 51 & 42.5 & 83.3 \\
\hline Source of capital & 20 & 16.7 & 100.0 \\
\hline \multicolumn{4}{|l|}{ Education level } \\
\hline College & 10 & 8.3 & 8.3 \\
\hline University & 106 & 88.3 & 96.7 \\
\hline Master's (MA) & 4 & 3.3 & 100.0 \\
\hline \multicolumn{4}{|c|}{ The average monthly salary } \\
\hline Less than 10 million & 23 & 19.2 & 19.2 \\
\hline Over 15 million & 43 & 35.8 & 55.0 \\
\hline From 10 to 15 million & 54 & 45.0 & 100.0 \\
\hline $\begin{array}{r}\text { Total } \\
\end{array}$ & 120 & 100.0 & \\
\hline
\end{tabular}

Data in Table 3 show that among the 120 respondents, $52.5 \%$ of the participants were male while the remaining 57 were female, representing for $47.5 \%$. Of these, 36 of them from 22 to 34 years old, accounting for $30.0 \%$; 10 of them over 45 years old, accounting for $8.3 \%$; and $61.7 \%$ of the participants were from 35 to 45 years old. Among the 120 respondents, accounting staff accounted for 31.7\%, Control staff accounted for $9.2 \%$, business staff accounted for $42.5 \%$, while the remaining 20 were Source of capital staff, accounted for $16.7 \%$. Of these, $46.7 \%$ of the participants have to 5 years and over 5 years accounted for $53.3 \%$. Of these, 120 respondents, of which 10 with college degrees, accounted for $8.3 \%$; 106 with university degrees, accounted for $88.3 \%$, MA degrees accounted for $3.3 \%$. Besides, Income from the average monthly salary of bank employees for less than 10.0 million VND accounted for $19.2 \%$; from 10.0 to 15.0 million, accounted for $45.0 \%$; Over 15.0 million 
VND accounted for $35.8 \%$.

Table 4: Descriptive Analysis of Attributes of bank employees' motivation

\begin{tabular}{|c|c|c|c|c|c|}
\hline & $\mathrm{N}$ & Minimum & Maximum & Mean & Std. Deviation \\
\hline WMBE1 & 120 & 3.0 & 5.0 & 4.150 & .7177 \\
\hline WMBE2 & 120 & 2.0 & 5.0 & 3.908 & .7778 \\
\hline WMBE3 & 120 & 2.0 & 5.0 & 4.042 & .7492 \\
\hline WMBE4 & 120 & 2.0 & 5.0 & 3.933 & .8671 \\
\hline WMBE5 & 120 & 2.0 & 5.0 & 3.683 & .756 \\
\hline WMBE6 & 120 & 1.0 & 5.0 & 3.933 & .796 \\
\hline Valid N (listwise) & 120 & & & $\mathbf{3 . 9 4 2}$ & \\
\hline
\end{tabular}

Data in Table 4 illustrate that the respondents agree with the dependent variable of "bank employees' motivation" where six attributes were quite high with an average of 3.942 compared with the highest of the Likert 5-point scale. All 6 attributes were rated at an average of 3.683 or higher.

Table 5: Descriptive Analysis of Attributes of work characteristics

(Independent variable)

\begin{tabular}{|c|c|c|c|c|c|}
\hline & $\mathrm{N}$ & Minimum & Maximum & Mean & Std. Deviation \\
\hline CW1 & 120 & 2.0 & 5.0 & 4.017 & .635 \\
\hline CW2 & 120 & 2.0 & 5.0 & 4.108 & .632 \\
\hline CW3 & 120 & 2.0 & 5.0 & 3.925 & .758 \\
\hline CW4 & 120 & 2.0 & 5.0 & 3.975 & .772 \\
\hline CW5 & 120 & 2.0 & 5.0 & 4.050 & .646 \\
\hline CW6 & 120 & 2.0 & 5.0 & 4.092 & .745 \\
\hline Valid N (listwise) & 120 & & & $\mathbf{4 . 0 2 8}$ & \\
\hline
\end{tabular}

Data in Table 5 illustrate that the respondents agree with the independent variable of "Work characteristics" where six attributes were quite high with an average of 4.028 compared with the highest of the Likert 5-point scale. All 6 attributes were rated at an average of 3.925 or higher.

\subsection{Cronbach's Alpha}

Bank employees' motivation has been measured by the Cronbach's Alpha. Results of testing Cronbach's alpha of attributes are presented in Table 6 as follows,

Table 6: Results of Cronbach's Alpha Testing of Attributes

\begin{tabular}{|c|c|c|c|c|}
\hline & $\begin{array}{c}\text { Scale Mean if } \\
\text { Item Deleted }\end{array}$ & $\begin{array}{c}\text { Scale Variance if } \\
\text { Item Deleted }\end{array}$ & $\begin{array}{c}\text { Corrected Item- } \\
\text { Total Correlation }\end{array}$ & $\begin{array}{c}\text { Cronbach's Alpha } \\
\text { if Item Deleted }\end{array}$ \\
\hline WMBE1 & 19.500 & 5.580 & .441 & .650 \\
\hline WMBE2 & 19.742 & 5.790 & .320 & .695 \\
\hline WMBE3 & 19.608 & 5.434 & .457 & .642 \\
\hline WMBE4 & 19.717 & 5.314 & .381 & .671 \\
\hline WMBE5 & 19.967 & 5.764 & .346 & .685 \\
\hline
\end{tabular}

The results also show that attributes of the dependent variable had a Cronbach's Alpha coefficient greater than 0.6; the correlation coefficient of all attributes was greater than 0.3 , so all the attributes of the dependent variable were statistically significant (Hoang \& Chu, 2008).

Work characteristics has been measured by the Cronbach's Alpha. Results of testing Cronbach's alpha of attributes are presented in Table 7 as follows,

Table 7: Results of Cronbach's Alpha Testing of Attributes (independent variable)

\begin{tabular}{|c|c|c|c|c|}
\hline & $\begin{array}{c}\text { Scale Mean if } \\
\text { Item Deleted }\end{array}$ & $\begin{array}{c}\text { Scale Variance if } \\
\text { Item Deleted }\end{array}$ & $\begin{array}{c}\text { Corrected Item- } \\
\text { Total Correlation }\end{array}$ & $\begin{array}{c}\text { Cronbach's Alpha } \\
\text { if Item Deleted }\end{array}$ \\
\hline CW1 & 20.15 & 7.305 & .616 & .815 \\
\hline CW2 & 20.06 & 7.165 & .666 & .806 \\
\hline CW3 & 20.24 & 6.924 & .582 & .822 \\
\hline CW4 & 20.19 & 6.862 & .584 & .822 \\
\hline CW6 & 20.12 & 7.112 & .665 & .806 \\
\hline
\end{tabular}

The results also show that attributes of the independent variable had a Cronbach's Alpha coefficient greater than 0.6 ; the correlation coefficient of all attributes was greater than 0.3 , so all the attributes of the independent variable were statistically significant (Hoang \& Chu, 2008). 


\subsection{Exploratory Factor Analysis (EFA)}

We then conducted Exploratory Factor Analysis (EFA). We used methods of extracting coefficients were component and Varimax analyses of the 6 observed independent variable. As can be seen in Table 8 , the results of the EFA show that $0.5<\mathrm{KMO}=0.785<1$. Barlett's testimony shows sig. $=0.000<0.05$. It means that all variables are interrelated.

Table 8: KMO and Bartlett's Test

\begin{tabular}{|l|l|r|}
\hline Kaiser-Meyer-Olkin Measure of Sampling Adequacy. & .785 \\
\hline Bartlett's Test of Sphericity & Approx. Chi-Square & 278.772 \\
\cline { 2 - 3 } & Df & 15 \\
\cline { 2 - 3 } & Sig. & 0.000 \\
\hline
\end{tabular}

After implementing the rotation matrix, we got the followings: one determinant with factor load $>0.5$, Eigenvalues $>1$, and the variance explained $=56.27 \%$. It demonstrates that the factor analysis of the research data is appropriate.

Through the quality assurance of the scale and the test of the EFA model, one factor that influence on bank employees' motivation of, i.e. WCs were identified.

\subsection{Correlation analysis}

As can be seen in Table 9, the results of the correlation matrix of the factors. The correlation coefficient of one factor with dependent variable is $0.571>0$, reflect a positive relationship, sig. $=0.003<0.05$. It means that all variables are interrelated, were statistically significant.

Table 9: Correlations

\begin{tabular}{|l|l|c|c|}
\hline \multicolumn{2}{|c|}{} & Bank employees' motivation & Work characteristics \\
\hline \multirow{3}{*}{ Bank employees' motivation } & Pearson Correlation & 1 & .517 \\
\cline { 2 - 4 } & Sig. (2-tailed) & & .003 \\
\cline { 2 - 4 } & $\mathrm{N}$ & 120 & 120 \\
\hline \multirow{3}{*}{ Work characteristics } & Pearson Correlation & .517 & 1 \\
\cline { 2 - 4 } & Sig. (2-tailed) & .003 & 120 \\
\cline { 2 - 4 } & $\mathrm{N}$ & 120 & \\
\hline
\end{tabular}

\section{Discussion}

Bank staffs highly appreciate the work characteristics factor. In fact, bank staffs have a deep understanding of what they have to do as well as the essential skills needed when performing. However, some problems are beyond their ability but they still have to do, which leads to bank employees' dissatisfaction, especially in terms of employees in the business department (Nguyen \& Pham, 2017). These matters which are out of their capability are often not mentioned in the bank employees' job description.

Communication skill is also a demanding requirement for bank staffs. They have to communicate with their superiors, customers, and colleagues. When communicating with superiors, bank staffs often report the progress in assigned work, ask for suggestion on how to handle profession-related situations. In communication with their customer, employees provide advice on selecting services, guidance, and introduction on rights and benefits when customer use the bank's products and services. When it comes to their colleagues, bank staffs often aim to share their own experiences in handling situations and discuss methods of coordinating to complete their work effectively (Pham, 2016a).

Work characteristics affect the motivation of bank employees. This is of importance for managers in designing the work for their employees to make a great effort to benefit the organization. Besides, managers also get solutions when applying the above theoretical model such as measures of work expansion, work enrichment, work mobility, etc.

\section{Recommendations}

The work characteristics of the bank are challenging, demanding with high pressure, thus, creating the most favorable working conditions will reduce stress, guarantee the high-level working spirit for employees. Therefore, bank managers need to research effective methods and support tools which assist employees to promote their competencies and ensure the completion of work as planned (Nguyen Quoc Nghi, 2012). In addition, timely support and encouragement for subordinates, listening to ideas and recognizing achievements from superiors will reduce work pressure, contribute to improving work motivation and efficiency in performance.

Improving the understanding of bank employees for their work: Bank managers need to improve, focus and detail more and more on the job description. In addition, professional training or training on the job is essential which help employees gain deeper insight into position, responsibility, and interactivity at work. Interruptions, 
overlap or lack of connections between departments should be carefully reviewed on a regular basis. Banks also need to consider the actual performance, aspiration, and capability of each employee to assign appropriately.

\section{References}

1. Bui, T.M.T, \& Le, N.D.K. (2014), The study of the work motivation of direct production employees in erection corporation Vietnam (lilama), science journal of Cantho University, No. 35, 66-78.

2. Bui, T.M.T, \& Le, N.D.K. (2016), The study of the work motivation of mechanical employees in the central key economic region, Central Social Science journal, No 1 (39), 24-38.

3. Farhann, A. (2009), Employees motivation at Areco India manufacturing private Limited, The M.B.A Degree Course of Bangalore University, June, 38.

4. Hackman, J.R. \& Oldham, G.R. (1980), Work redesign, Mass, Addison-Wesley.

5. Hair, J.F., Joseph, F.Jr., Anderson, Rolph E., Tatham, Ronald L. and Black, Wiliam C., (1998), Multivariate data analysis, $5^{\text {th }}$ edition, Prentice Hall, Upper Saddle River, NJ.

6. Herzberg, F., Mausner, B., \& Snyderman, B.B. (1959), The Motivation to Work, 2ned, New York, London, Sydney, John Wiley \& Son, Inc.

7. Hoang, T., \& Chu, N.M.N (2008), Analysis of research data with SPSS, Hong Duc Publishing House.

8. Nguyen, B.H. (2017), Factors affecting work motivations of workers: The case of Thang Long cementjointstock company, Journal of trade science, No 111/2017, 55-62.

9. Nguyen, Q.N. (2012), Determinants influencing the loyalty of bank employees, Journal of Development Economic, No 259, 22-29.

10. Nguyen, T. D. (2015), Factors affecting work motivation of the lectures of universities in Hanoi, Ph.d. thesis, National Economics University, Vietnam.

11. Nguyen, V.T. \& Pham, X.T (2017), Employee satisfaction in HD Bank Ho Chi Minh, Banking Technology Review, No 135, 102-113.

12. Pham, T.T.H. (2016), Study the working motivation of workers in small and medium enterprises in Hai Phong city, Economy and forecast Review), No 20, 43-46.

13. Pham, T.T. (2016a), The content of communication and the impact of the content of communication on the performance of employees of Vietnamese commercial banks, Psychology Journal, No 4 (205), 51-61. 